\title{
PRZESUNIĘCIA W OBRĘBIE LEKSYKALNEGO SCHEMATU KOHEZYWNEGO W TŁUMACZENIU SYMULTANICZNYM I KONSEKUTYWNYM
}

\begin{abstract}
Zarys treści: Niniejszy artykuł podejmuje próbę analizy przesunięć w obrębie leksykalnego schematu kohezywnego w procesie tłumaczenia symultanicznego i konsekutywnego. Biorąc pod uwagę odmienną specyfikę tych dwóch różnych typów tłumaczenia konferencyjnego, można spodziewać się znacznych rozbieżności, jeżeli chodzi o oddanie środków więzi w tekstach docelowych. Analiza została przeprowadzona na podstawie kryteriów ograniczeń typowych dla tłumaczenia ustnego (Interpreting Constraints): ograniczenia czasowego (The Time Constraint), wymogu linearności wypowiedzi (The Linearity Constraint), ograniczenia wynikającego z braku wspólnego kontekstu komunikacyjnego ( The (Un)shared Knowledge Constraint) oraz ograniczenia ze względu na pojemność pamięci ( The Memory Load Constraint).
\end{abstract}

Słowa kluczowe: tłumaczenie, tłumaczenie ustne, tłumaczenie symultaniczne, tłumaczenie konsekutywne. przesunięcia, schemat kohezywny

Tohezja leksykalna jest powszechnie uznawana za dominującą formę two- rzenia tekstury w porównaniu z innymi mechanizmami spajającymi, takimi jak referencja, koniunkcja, elipsa czy substytucja. Z badań przeprowadzonych przez Hoeya (1991) wynika, że leksykalne wykładniki spójności tekstu stanowią ponad czterdzieści procent wszystkich sygnałów nawiązania, składających się na kohezję tekstu. Obserwacje te potwierdzają także badania przeprowadzone przez Gajdę (1982). Rola, jaką kohezja leksykalna odgrywa w tworzeniu tekstu, to ustanowienie koreferencji pomiędzy poszczególnymi jednostkami leksykalnymi oraz zapewnienie ciągłości tematycznej tekstu (Pawelec 2000). 
Jak podkreślają Baker (1992) i Snell-Hornby (1988), sieć kohezywnych nawiązań leksykalnych determinuje w dużej mierze sens, w jakim poszczególne jednostki leksykalne zostały użyte w tekście.

Decydując się na wybór ekwiwalentów jednostek leksykalnych w języku docelowym, tłumacz musi brać pod uwagę fakt, że tworzą one sieć wzajemnie oddziałujących na siebie relacji, przyczyniając się w ten sposób do spójności tekstu. Jednak w obliczu nieprzystawalności systemów językowych (np. braku ekwiwalentów lub wieloznaczności leksykalnej czy strukturalnej), różnic stylistycznych oraz obowiązujących norm przekładowych, odtworzenie leksykalnego schematu kohezywnego w tekście docelowym, który spełniałby wymogi ekwiwalencji, zarówno formalnej, jak i funkcjonalnej, może okazać się niemożliwe (Baker 1992). Jak podkreślają Hatim i Mason (1990), dostosowanie leksykalnego schematu kohezywnego do strukturalnych, stylistycznych i normatywnych wymogów języka docelowego jest jednym z czynników, które bierze się pod uwagę, oceniając jakość przekładu. Oczywiście należy zdawać sobie sprawę, że tego typu modyfikacje prowadzą nieuchronnie do przesunięć w obrębie leksykalnego schematu kohezywnego. Nie jest to jednak jedyny czynnik powodujący tego typu zmiany. Hipoteza Blum-Kulki (1986) zakłada, że modyfikacje schematu kohezywnego należy uznać za uniwersalne dla jakiegokolwiek procesu mediacji językowej, w tym również przekładu. Z kolei, według Shlesinger (1995), sposób oddania schematu kohezywnego tekstu wyjściowego jest zależny od rodzaju przekładu. Jej badania, przeprowadzone na tekstach thumaczonych symultanicznie, wykazały, że ten typ przekładu charakteryzuje się znacznymi przesunięciami w obrębie schematu kohezywnego ${ }^{1}$.

Teza Shlesinger o zależności pomiędzy sposobem oddania sieci mechanizmów spajających a rodzajem przekładu posłużyła za punkt wyjścia do badań przedstawionych $w$ niniejszym artykule. Celem pracy jest zbadanie rozbieżności w oddaniu leksykalnego schematu kohezywnego pomiędzy thumaczeniem symultanicznym a konsekutywnym.

Przekład symultaniczny i konsekutywny znacznie różnią się od siebie, chociaż oba sposoby mediacji językowej są przecież formami tłumaczenia ustnego. Odmienną specyfikę tych dwóch różnych typów tłumaczenia konferencyjnego można chyba najpełniej scharakteryzować, odnosząc się do kryteriów ograniczeń typowych dla thumaczenia ustnego (Interpreting Constraints).

Termin Interpreting Constraints po raz pierwszy pojawił się we wspomnianej już pracy izraelskiej badaczki Miriam Shlesinger (1995), w której wspomina

\footnotetext{
${ }^{1}$ Wśród innych prac poruszających problem kohezji leksykalnej w przekładzie należy wymienić badania Lotfipoura-Saedi'ego (1997), Niskiej (1999: 24ff), Mizuno (1999: 36ff), Klaudy i Károly (2002) oraz Łydy i Gumul (2002: 353ff).
} 
ona o trzech ograniczeniach charakterystycznych dla przekładu symultanicznego. Są to: ograniczenie czasowe (The Time Constraint), wymóg linearności wypowiedzi (The Linearity Constraint) oraz ograniczenia wynikające z braku wspólnego kontekstu komunikacyjnego (The (Un)shared Knowledge Constraint). Jednak, aby w pełni oddać rozbieżności pomiędzy thumaczeniem symultanicznym a konsekutywnym, należy wziąć pod uwagę również czwarte kryterium, a mianowicie - ograniczenie ze względu na pojemność pamięci (The Memory Load Constraint).

Model analizy przekładu obejmujący wszystkie cztery kryteria ograniczeń ${ }^{2}$ opiera się $\mathrm{w}$ dużej mierze na teorii przetwarzania informacji (Informationprocessing theory), a w szczególności na modelach wysiłkowych (Effort Models) zaproponowanych przez Gile'a (1990, 1995, 1997, 2001).

Poruszając kwestię ograniczenia czasowego w przekładzie ustnym, należy przede wszystkim podkreślić, że choć problem ten dotyczy zarówno thumaczenia symultanicznego, jak i konsekutywnego, to jednak presja czasowa jest oczywiście o wiele bardziej odczuwalna w przekładzie symultanicznym. Jak podkreśla Kirchhoff (1976), tempo nadawania komunikatu wyjściowego, którego thumacz nie jest w żaden sposób w stanie kontrolować, ma wpływ na wszystkie operacje składające się na proces tłumaczenia symultanicznego. Utrudnia to efektywne zarządzanie procesami przetwarzania informacji (processing capacity management) polegające na skoordynowaniu trzech, najczęściej jednoczesnych, operacji mentalnych: wysiłku związanego ze słuchaniem i analizą tekstu wyjściowego (the Listening and Analysis Effort), wysiłku związanego z produkcją tekstu docelowego (the Production Effort) oraz wysiłku związanego z obciążeniem pamięci krótkoterminowej (the short-term Memory Effort). Ponieważ w thumaczeniu symultanicznym sposób przetwarzania jednego segmentu tekstu ma bezpośredni wpływ na dostępność zasobów niezbędnych do przetwarzania informacji w kolejnym segmencie, istnieje ryzyko nadmiernego obciążenia pamięci krótkoterminowej, które może prowadzić do osiągnięcia granicy zdolności do przetwarzania informacji (processing capacity saturation) (Gile 1995, 1997). Dużą rolę odgrywa tu właściwe wykorzystanie strategii dostosowywania opóźnienia czasowego (EVS regulation), czyli wydłużania lub skracania przedziału czasowego dzielącego dany segment tekstu wystąpienia od jego przekładu. Umiejętne zastosowanie tej strategii pozwala thumaczowi kontrolować do pewnego stopnia zarządzanie procesami przetwarzania informacji (Gumul 2004, 2005: 178).

${ }^{2}$ Zaprezentowany w pracy Łydy i Gumul (2002: 349ff) oraz w szerszym wymiarze w pracy Gumul (2004: 39-79). 
Podstawowa różnica między tłumaczeniem konsekutywnym a symultanicznym, jeśli chodzi o ograniczenie czasowe, polega na tym, że w przekładzie konsekutywnym tylko pierwsza faza jest zagrożona nadmiernym obciążeniem pamięci krótkoterminowej. W tej fazie wysiłek związany ze słuchaniem i analizą tekstu wyjściowego zbiega się w czasie $\mathrm{z}$ wysiłkiem związanym ze sporządzaniem notatek (the Production Effort: Note-Taking). W ten sposób, podobnie jak $\mathrm{w}$ thumaczeniu symultanicznym, potrzebne są wystarczające zasoby mentalne, aby wykonać trzy niemalże jednoczesne operacje (Gile 2001). Jednak to, co stanowi dodatkowe ułatwienie w procesie przekładu konsekutywnego, to fakt, iż wysiłku związanego z produkcją tekstu docelowego w thumaczeniu symultanicznym nie można utożsamiać $\mathrm{z}$ wysiłkiem, jakiego wymaga sporządzanie notatek. Reekspresja tekstu w thumaczeniu konsekutywnym następuje na tyle szybko, że notatki mogą mieć charakter fragmentaryczny. Zatem opanowanie efektywnych technik notacyjnych ułatwia zarządzanie procesami przetwarzania informacji w tym typie thumaczenia ustnego (Gile 1995).

Kolejny czynnik stanowiący ograniczenie w thumaczeniu ustnym to wymóg linearności wypowiedzi (The Linearity Constraint). Jednak, w przeciwieństwie do ograniczenia czasowego, gdzie można było zaobserwować pewne analogie pomiędzy przekładem konsekutywnym a symultanicznym, w przypadku tego czynnika ograniczającego rozbieżności są znaczne. Omawiając wymóg linearności wypowiedzi, należy przede wszystkim odnieść się do modelu domen tekstowości Hatima i Masona (1997). Według tych badaczy przekład symultaniczny charakteryzuje się ułatwionym dostępem do tekstury (texture), a jednocześnie utrudnionym dostępem do struktury. W thumaczeniu konsekutywnym sytuacja jest odwrotna.

Termin „tekstura” odnosi się do wewnętrznej budowy tekstu. Są to wszystkie te środki gramatyczne i leksykalne, które zapewniają spójność tekstu zarówno pod względem formalnym (kohezja), jak i w kategoriach semantycznego powiązania treściowych składników tekstu (koherencja). Struktura natomiast to swoisty plan tekstu (Hatim \& Mason 1997).

W przekładzie symultanicznym segmenty tekstu wyjściowego docierające każdorazowo do tłumacza obejmują przedział czasowy nie dłuższy niż kilka sekund. Tłumacz zmuszony jest więc do odtworzenia tekstu i odbudowania jego struktury na podstawie lokalnych wykładników spójności tekstu tworzących jego teksturę (Hatim, Mason 1997; por. Gumul 2004). Inaczej rzecz się ma z przekładem konsekutywnym ${ }^{3}$, gdzie tekst wyjściowy jest zaprezentowany $\mathrm{w}$

\footnotetext{
${ }^{3}$ Mowa tu oczywiście o wariancie konferencyjnym tłumaczenia konsekutywnego. Sytuacja wygląda zgoła inaczej w thumaczeniu towarzyszącym (liaison interpreting), w
} 
całości lub we fragmentach wystarczająco obszernych, aby można je było określić mianem „mikrotekstów”, mających własną strukturę. W takich warunkach wszystkie informacje składające się na teksturę thumaczonego dyskursu stają się zbyt szczegółowe, aby można je było zapamiętać i odtworzyć bez trudu. Tłumacz musi zatem polegać na strukturze tekstu, aby móc chociaż w przybliżeniu odtworzyć jego teksturę.

Ograniczenia wynikające $\mathrm{z}$ braku wspólnego kontekstu komunikacyjnego (The (Un)shared Knowledge Constraint) to kolejny czynnik utrudniający pracę thumacza słowa żywego. Specyfika thumaczenia ustnego polega na tym, że chociaż służy ono komunikacji, nie można go uznać za naturalną sytuację komunikacyjną. Tłumacz nie jest ani interlokutorem, który na ogół posiada taką samą ramę referencyjną (reference frame) jak nadawca komunikatu, ani też przypadkowym słuchaczem, który nie jest zobligowany aby w pełni zrozumieć nadawany komunikat (Seleskovitch 1978). Zapasy poznawcze thumacza na ogół różnią się znacznie od tych, jakie posiadają uczestnicy konferencji i nie zawsze pozwalają na wydobycie sensu pewnych segmentów tekstu wyjściowego. Nawet najlepiej przygotowany thumacz nie dysponuje przecież taką ilością wiedzy specjalistycznej, jaką posiadają pozostali uczestnicy tego aktu mediacji językowej. Taka sytuacja prowadzi niejednokrotnie do powstania luki informacyjnej, utrudniając tym samym proces komunikacji za pośrednictwem thumacza.

Pomimo że problem braku wspólnego kontekstu komunikacyjnego wydaje się dotyczyć w równym stopniu zarówno przekładu symultanicznego, jak i konsekutywnego, to jednak specyfika tego ostatniego umożliwia w pewnych wypadkach podjęcie działań, które pozwolą uniknąć tego typu problemów. Z uwagi na to, że tłumacz konsekutywny ma dostęp do większych segmentów tekstu wyjściowego, a fazę reekspresji dzieli od fazy rozumienia pewien przedział czasowy, możliwa staje się dedukcja znaczenia problematycznych jednostek leksykalnych na podstawie kontekstu.

Ostatnim z omawianych czynników jest ograniczenie ze względu na pojemność pamięci (The Memory Load Constraint). Jak wynika z modeli wysiłkowych skonstruowanych przez Gile'a, w tłumaczeniu symultanicznym kluczową rolę odgrywa pamięć krótkoterminowa, natomiast w thumaczeniu konsekutywnym, w zależności od fazy, tłumacz posiłkuje się albo pamięcią krótkoterminową, albo długoterminową (Gile 1995, 2001). Jednak należy podkreślić, że użycie przez Gile'a terminów pamięć krótko- i długotrwała w kontekście modeli wysiłkowych nie do końca oddaje złożoność problemu pamięci w przekładzie konsekutywnym. Oczywiście niezbędne jest odniesienie się do pamięci długo-

którym dostęp do struktury jest równie utrudniony, jak w przekładzie symultanicznym (por. Hatim, Mason 1997: 42ff; Łyda, Gumul 2002: 348; Gumul 2004: 54ff). 
trwałej, w której zmagazynowane są niezbędne do zrozumienia i odtworzenia tekstu zapasy poznawcze, podobnie zresztą jak w thumaczeniu symultanicznym. Jednak to, co utrudnia odtworzenie tekstu wyjściowego na podstawie notatek w thumaczeniu konsekutywnym, to ograniczona pojemność pamięci opera-cyjnej.

Zatem termin „ograniczenie ze względu na pojemność pamięci” odnosi się głównie do ograniczonej pojemności pamięci operacyjnej w tłumaczeniu konsekutywnym. Problemy związane z ograniczeniami pamięci krótkotrwałej (zarówno ikonicznej, czyli chwilowej, jak i operacyjnej) w przekładzie symultanicznym zostały omówione w kontekście ograniczenia czasowego, ponieważ są one bezpośrednio związane z tym zjawiskiem.

Omówione różnice, jakie można zaobserwować między przekładem symultanicznym a konsekutywnym, pozwalają przypuszczać, że mają one bezpośredni wpływ na rozbieżności $\mathrm{w}$ oddaniu leksykalnego schematu kohezywnego pomiędzy tymi dwoma rodzajami thumaczenia ustnego.

Analizowane w niniejszym artykule powierzchniowe wykładniki spójności tekstu to jeden z rodzajów reiteracji (reiteration) wyróżnionych przez Hallidaya i Hasan (1976) - tj. powtórzenia, na które składają się powtórzenia dokładne i powtórzenia częściowe.

Materiał badawczy stanowi zbiór 96 nagrań (2 teksty, z których każdy został przetłumaczony przez 48 tłumaczy). Osoby biorace udział w eksperymencie to studenci III i V roku filologii angielskiej Uniwersytetu Śląskiego kształcący się w ramach programu thumaczenia pisemnego i ustnego. Hipoteza zakładająca różnice $\mathrm{w}$ realizacji schematu kohezywnego w tekstach docelowych pomiędzy thumaczeniem konsekutywnym a thumaczeniem symultanicznym, wynikająca $z$ ograniczeń typowych dla każdego z tych sposobów przekładu, została zweryfikowana za pomocą testu t-Studenta dla porównywania średnich wartości. Z uwagi na to, że celem pracy jest zbadanie zależności pomiędzy sposobem oddania schematu kohezywnego a rodzajem przekładu, z analizy wykluczono wszystkie te przykłady, w których wszelkie zmiany można przypisać różnicom strukturalnym pomiędzy językami wyjściowym i docelowym lub odmiennym preferencjom stylistycznym.

Dla potrzeb analizy realizacji schematu kohezywnego wyodrębniono trzy główne rodzaje strategii: zachowanie tego samego rodzaju nawiązania leksykalnego (Z), zmianę kategorii (ZM) lub pominięcie analizowanego środka więzi (P).

Analiza ilościowa przeprowadzona za pomocą testu t-Studenta dla porównywania średnich wartości wykazała statystycznie istotną różnicę - jeśli chodzi o oddanie leksykalnych środków nawiązania (poziom istotności 0,05 ) - pomiędzy przekładem konsekutywnym a symultanicznym. Zachowanie tej samej ka- 
tegorii środka więzi przeważa $\mathrm{w}$ thumaczeniu symultanicznym, natomiast $\mathrm{w}$ przekładzie konsekutywnym można zaobserwować o wiele więcej przypadków pominięcia przynajmniej jednej z jednostek leksykalnych tworzących relację kohezywną:

Tabela 1. Kohezja leksykalna (kategoria Powtórzenie) - wyniki testu t-Studenta dla porównywania średnich wartości

\begin{tabular}{|c|c|c|c|}
\hline & Średnia art. + odch. STD & Poziom istotności $p$ & Wniosek \\
\hline $\mathrm{TK}^{4}-\mathrm{Z}$ & $3,833+/-3,07$ & \multirow[b]{2}{*}{$p<0,05$} & \multirow[b]{2}{*}{$\mathrm{m}_{\mathrm{TK}}<\mathrm{m}_{\mathrm{TS}}$} \\
\hline $\mathrm{TS}-\mathrm{Z}$ & $6,444+/-3,69$ & & \\
\hline TK-ZM & $1,888+/-1,73$ & \multirow[b]{2}{*}{$p>0,05$} & \multirow[b]{2}{*}{$\mathrm{m}_{\mathrm{TK}}=\mathrm{m}_{\mathrm{TS}}$} \\
\hline TS - ZM & $1,194+/-1,43$ & & \\
\hline $\mathrm{TK}-\mathrm{P}$ & $6,277+/-3,79$ & \multirow[b]{2}{*}{$\mathrm{p}<0,05$} & \multirow[b]{2}{*}{$\mathrm{m}_{\mathrm{TK}}>\mathrm{m}_{\mathrm{TS}}$} \\
\hline $\mathrm{TS}-\mathrm{P}$ & $4,361+/-3,53$ & & \\
\hline
\end{tabular}

Charakterystyczną cechą kohezji leksykalnej jest to, że relacja nawiązania bardzo często przybiera formę wieloelementowych łańcuchów złożonych z kilku lub nawet kilkunastu rozrzuconych w tekście jednostek leksykalnych. Wynika $\mathrm{z}$ tego, że analizie powinna podlegać całość łańcucha nawiązań. Jednak ze względu na zróżnicowanie relacji zachodzących pomiędzy poszczególnymi elementami w obrębie jednego łańcucha zostały one podzielone na pary nawiązań kohezywnych. Ilustruje to fragment jednego z analizowanych tekstów:

Tekst wyjściowy $(1-4 / \mathrm{T} 1)$ :

[...] but for the moment all I want you to do/is to keep the fact of this double centre in mind/and to consider/in a fairly general way/what the early (1) consequences were

well/the first (2) consequence I suppose/is that the importance of the river itself/was increased//obviously/the river/was from the/from the beginning/vitally important/as the link with the outside world/the route followed by almost all traffic/with the Continent/but in addition to this/it was also in the first place/the most important means of communication between the town centred on the Roman fort/which subsequently grew into the city of London/the city of trade/and of the Merchant Guilds/and the other town/focused on the Abbey/the Royal City of Westminster

that was the first and in many ways the most vital (3) consequence of the double centre / as we've called it // but now before mentioning some of the other (4) consequences / and there were many of them / some very important / some much less so / now I'd like if I may / to spend some time on this matter of internal communications // I'd like you to consider what happened as the two towns began to expand / what do you think the main (5) consequences of expansion were /

\footnotetext{
${ }^{4}$ TK - thumaczenie konsekutywne; TS - thumaczenie symultaniczne.
} 
Relacja zachodząca między dwoma pierwszymi elementami to relacja włączenia (inclusion). Drugi i trzeci element łączy relacja identyczności referencji (identity of reference). Są one zatem koreferencyjne. Podobnie rzecz się ma $\mathrm{z}$ dwoma ostatnimi elementami tego łańcucha. $Z$ kolei relację zachodzącą pomiędzy elementami 3 i 4 można określić mianem relacji wyłączenia (exclusion), jako że nie mają one wspólnego desygnatu. W ten sposób łańcuch ten został podzielony na cztery odrębnie analizowane przykłady relacji nawiązań kohezywnych.

Zestawienia procentowe przedstawione w tabeli 2 wskazują, że największe rozbieżności pomiędzy przekładem konsekutywnym a symultanicznym, jeśli chodzi o zachowanie tej samej kategorii środka więzi, można zaobserwować w przypadku relacji łączącej dwa pierwsze elementy analizowanego łańcucha.

Tabela 2. Procentowe zestawienie wyników

\begin{tabular}{|l|l|l|l|l|l|l|l|c|}
\hline \multirow{2}{*}{} & \multicolumn{2}{|c|}{$1 / \mathrm{T} 1$} & \multicolumn{2}{c|}{$2 / \mathrm{T} 1$} & \multicolumn{2}{c|}{$3 / \mathrm{T} 1$} & \multicolumn{2}{c|}{ 4/T1 } \\
\cline { 2 - 10 } & TK & TS & TK & TS & TK & TS & TK & TS \\
\hline Zachowanie & $37,5 \%$ & $87,5 \%$ & $54,17 \%$ & $87,5 \%$ & $66,67 \%$ & $87,5 \%$ & $58,33 \%$ & $87,5 \%$ \\
\hline Pronominalizacja & $0 \%$ & $4,17 \%$ & - & - & - & - & - & - \\
\hline Elipsa & - & - & $12,5 \%$ & $4,17 \%$ & - & - & - & - \\
\hline Parafraza & $8,33 \%$ & $8,33 \%$ & - & - & $4,17 \%$ & $8,33 \%$ & $4,17 \%$ & $8,33 \%$ \\
\hline $\begin{array}{l}\text { Pominięcie wykładnika } \\
\text { spójności tekstu }\end{array}$ & $25 \%$ & $4,17 \%$ & $4,17 \%$ & $0 \%$ & $4,17 \%$ & $4,17 \%$ & $12,5 \%$ & $4,17 \%$ \\
\hline $\begin{array}{l}\text { Pominięcie fragmentu } \\
\text { tekstu }\end{array}$ & $25 \%$ & $0 \%$ & $8,33 \%$ & $4,17 \%$ & $4,17 \%$ & $4,17 \%$ & $25 \%$ & $0 \%$ \\
\hline $\begin{array}{l}\text { Zniekształcenie frag- } \\
\text { mentu tekstu }\end{array}$ & - & - & $4,17 \%$ & $0 \%$ & $4,17 \%$ & $0 \%$ & - & - \\
\hline
\end{tabular}

Analiza tekstu wyjściowego wykazuje, że znaczną część przypadków pominięcia (pominięcia wykładnika spójności tekstu oraz pominięcia fragmentu tekstu stanowią razem 50\%) w thumaczeniu konsekutywnym można prawdopodobnie przypisać rozdzieleniu elementów tworzących analizowaną relację. Ponieważ występują one $\mathrm{w}$ odrębnych segmentach tekstu, pojawienie się drugiego członu relacji nawiązania jest opóźnione w czasie. W tych warunkach bardziej prawdopodobne jest, że wystąpi zmiana kategorii relacji spajającej lub pominięcie drugiego elementu relacji nawiązania.

Jednak w tym przypadku w większości tekstów docelowych zaobserwowano pominięcie pierwszego elementu. Może to być spowodowane jego umiejscowieniem w końcowej części segmentu. Tezę tę potwierdza wyższy odsetek zachowania tej samej kategorii relacji spajającej w thumaczeniu konsekutywnym w przykładzie 2/T1 (Tabela 2), w którym dwa elementy tworzące relację 
kohezywną również znajdują się w oddzielnych segmentach, ale obydwa występują na początku segmentów.

Elementy występujące w końcowej części segmentu są szczególnie narażone na pominięcie w przekładzie ustnym. Jest to najczęściej spowodowane gęstością informacyjną poprzedzającej części dyskursu zawierającej potencjalne źródła problemów (problem triggers), które mogą utrudnić efektywne zarządzanie procesami przetwarzania informacji potrzebne do tego, aby skoordynować trzy jednoczesne operacje mentalne zachodzące w pierwszej fazie thumaczenia konsekutywnego: wysiłek związany ze słuchaniem i analizą tekstu wyjściowego (the Listening and Analysis Effort), wysiłek związany ze sporządzaniem notatek (the Production Effort: Note-Taking) oraz wysiłek związany $\mathrm{z}$ obciążeniem pamięci krótkoterminowej (the Short-term Memory Effort). Oczywiście utrudnienie to występuje również $\mathrm{w}$ thumaczeniu symultanicznym. Jednak, jak wynika $\mathrm{z}$ analizy tekstów docelowych, ułatwiony dostęp do tekstury charakterystyczny dla tego rodzaju przekładu umożliwia odtworzenie relacji nawiązania.

\section{Tekst wyjściowy (1/T1):}

[...] but for the moment all I want you to do / is to keep the fact of this double centre in mind / and to consider / in a fairly general way / what the early consequences were

well / the first consequence I suppose / is that the importance of the river itself [...]

Tekst docelowy (nr 25/TK):

[...] teraz chciałbym tylko, żeby zapamiętali państwo fakt tego jakby podwójnego rozwoju / czy rozwoju w dwóch kierunkach, jakiemu podlegał Londyn / i rozważyli jego wpływ na przyszłość Londynu

pierwszym skutkiem takiego rozwoju sytuacji było na pewno to że rzeka / czyli Tamiza / stała się jeszcze bardziej ważna dla osadników / [...]

REITERACJA (POWTÓRZENIE) $\Rightarrow$ POMINIĘCIE WYKŁADNIKA SPÓJNOŚCI TEKSTU

Tekst docelowy (nr 35/TK):

[...] ale teraz chciałbym żebyście państwo przede wszystkim pamiętali o tym / o tych dwóch centrach Londynu // i zastanowili się jaki to miało wpływ na wczesny jego rozwój

przede wszystkim chciałbym zauważyć jak bardzo wzrosła waga rzeki / [...]

REITERACJA (POWTÓRZENIE) $\Rightarrow$ POMINIĘCIE WYKŁADNIKA SPÓJNOŚCI TEKSTU

Tekst docelowy (nr 21/TS): 
[...] ale na razie chcę tylko żeby państwo pamiętali o tym podwójnym scentrowaniu // i zastanowimy się jakie były wczesne konsekwencje tego

myślę że pierwszą konsekwencją jest / to że ważność rzeki / znaczenie rzeki wzrosło / [...]

REITERACJA (POWTÓRZENIE) $\Rightarrow$ REITERACJA (POWTÓRZENIE)

Jak wynika z analizy fragmentów tekstów docelowych w przykładzie 3/T1, czynnikiem, który może spowodować zmianę kategorii środka więzi, jest bliskość powtórzonych elementów. W miejsce powtórzenia zastosowano elipsę $(16,5 \%)$ lub parafrazę $(12,5 \%)$. Użycie parafrazy można w tym przypadku przypisać specyfice thumaczenia konsekutywnego, w którym tempo nadawania komunikatu docelowego nie jest uzależnione od tempa wygłaszania tekstu wyjściowego, i tym samym umożliwia thumaczowi znalezienie synonimicznego ekwiwalentu, aby uniknąć stylistycznie niezręcznego powtórzenia. Kolejnym potencjalnym czynnikiem, który należy wziąć pod uwagę, jest ograniczony dostęp do tekstury utrudniający odtworzenie tego samego rodzaju mechanizmów spajających, tym bardziej że cytowany poniżej fragment tekstu wyjściowego pochodzi z segmentu liczącego 155 wyrazów, cechującego się dodatkowo znaczną gęstością semantyczną.

Tekst wyjściowy (3/T1):

that was the first and in many ways the most vital consequence of the double centre / as we've called it // but now before mentioning some of the other consequences / and there were many of them / some very important / some much less so / [...]

Tekst docelowy (nr 26/TK):

pierwszą / najważniejszą konsekwencją rozdwojenia samego miasta / koncentracji wokół dwóch ośrodków / była oczywiście rzeka / ale zanim wspomnę o / innych [...] / a niektóre z nich są bardziej istotne / niektóre mniej / [...]

REITERACJA (POWTÓRZENIE) $\Rightarrow$ ELIPSA

Tekst docelowy (nr 25/TK):

to był / to była pierwsza konsekwencja tego efektu który nazywamy podwójnym centrum / jest jeszcze oczywiście więcej innych skutków / mniej lub bardziej ważnych / [...]

REITERACJA (POWTÓRZENIE) $\Rightarrow$ REITERACJA (PARAFRAZA)

Utrudniony dostęp do tekstury może również tłumaczyć wysoki odsetek przypadków zmian kategorii w przykładzie 5/T1. 25\% badanych zastosowało 
pronominalizację $\mathrm{w}$ miejsce powtórzenia $\mathrm{w}$ tłumaczeniu konsekutywnym. Odwrotnie niż w przekładzie symultanicznym, gdzie $41 \%$ zachowało tę samą kategorię środka więzi, a tylko 4,17\% użyło zaimka, czyli pro-formy zamiast rzeczownika, czyli wersji pełnej.

Tekst wyjściowy (5/T1):

now / by way of introduction / I'd like to try and give some indication of how London itself originated // of what developmental trends were built into it / as it were from the very outset / and of how / these trends have affected its growth / [...]

Tekst docelowy (nr 32/TK):

tak więc / słowem wstępu / chciałbym państwu powiedzieć w jaki sposób doszło do powstania Londynu

i jakie zewnętrzne trendy rozwojowe / miały tutaj miejsce i w jaki sposób wpłynęły one na wzrost $[\ldots]$

REITERACJA (POWTÓRZENIE) $\Rightarrow$ PRONOMINALIZACJA

Tekst docelowy (nr 39/TS):

słowem wstępu chciałbym powiedzieć skąd / w jaki sposób narodził się Londyn / jakie trendy rozwojowe / tam miały miejsce / i w jaki sposób // i jak różnie / te trendy wpłynęły na jego rozwój / [...]

REITERACJA (POWTÓRZENIE) $\Rightarrow$ REITERACJA (POWTÓRZENIE)

Analiza materiału badawczego wykazała, że zjawisko przesunięć w obrębie leksykalnego schematu kohezywnego występuje znacznie częściej w przekładzie konsekutywnym niż symultanicznym. Podsumowując czynniki powodujące modyfikacje schematu kohezywnego tekstu wyjściowego, należy podkreślić, że powody, dla których kohezja ulega zmianom w procesie tłumaczenia ustnego, warunkowane są ograniczeniami charakterystycznymi dla danego typu przekładu. W thumaczeniu konsekutywnym należy wymienić w pierwszym rzędzie ograniczony dostęp do tekstury oraz znaczne obciążenie pamięci. Nie bez znaczenia są także ograniczenia czasowe oraz potencjalne problemy wynikające z konieczności koordynacji kilku jednoczesnych czynności, utrudniających zarządzanie procesami przetwarzania informacji w pierwszej fazie thumaczenia konsekutywnego. W przekładzie symultanicznym dominują inne czynniki, wśród których decydujące znaczenie ma presja czasowa, o wiele wyraźniejsza niż w przypadku thumaczenia konsekutywnego. 


\section{Literatura}

Baker, M. 1992, In Other Words: A Coursebook on Translation, London-New York.

Blum-Kulka, S. 1986, Shifts in Cohesion and Coherence in Translation, [w:] Interlingual and Intercultural Communication: Discourse and Cognition in Translation and Second Language Acquisition Studies, red. J. House i S. Blum-Kulka, Tübingen, s. 17-35.

Gajda, S. 1982, Podstawy badań stylistycznych nad językiem naukowym, Warszawa-Wrocław.

Gile, D. 1995, Basic Concepts and Models for Interpreter and Translator Training, Amsterdam-Philadelphia.

Gile, D. 1997, Conference Interpreting as a Cognitive Management Problem, [w:] Cognitive Processes in Translation and Interpreting, red. J. Danks i in., London, s. 196-214.

Gile, D. 2001, The Role of Consecutive in Interpreter Training: A Cognitive View (http://www.aiic.net/ViewPage.cfm/page377.htm)

Gumul, E. 2004, Cohesion in Interpreting, niepubl. pr. dokt., Uniwersytet Śląski, Katowice.

Gumul, E. 2005, EVS: czynnik czasu w thumaczeniu symultanicznym, [w:] Czas w języku i kulturze, red. A. Arabski, E. Borkowska i A. Łyda, Katowice, s. 176-183.

Halliday, M. A. K., Hasan, R. 1976, Cohesion in English, London-New York.

Hatim, B., Mason, I. 1990, Discourse and the Translator, London-New York.

Hatim, B., Mason, I. 1997, Translator as a Communicator, Amsterdam Philadelphia.

Hoey, M. 1991, Patterns of Lexis in Text, Oxford.

Kirchhoff, H. 1976, Simultaneous Interpreting: Interdependence of Variables in the Interpreting Process, Interpreting Models and Interpreting Strategies, [w:] The Interpreting Studies Reader, red. F. Pöchhacker i M. Shlesinger, 2002, London and New York, s. 110-119.

Klaudy, K., Károly, K. 2002, Lexical Repetition in Professional and Trainees' Translation, [w:] Teaching Translation and Interpreting 4. Building Bridges, red. E. Hung, Amsterdam-Philadelphia, s. 99-113.

Lotfipour-Saedi, K. 1997, Lexical Cohesion and Translation Equivalence', Meta 42(1): 187-192.

Łyda, A., Gumul, E. 2002, Cohesion in Interpreting', [w:] PASE Papers in Language Studies: Proceedings of the Ninth Annual Conference of the 
Polish Association for The Study of English, red. D. Stanulewicz, Gdańsk, s. 349-356.

Mizuno, A. 1999, Shifts of Cohesion and Coherence in Simultaneous Interpretation from English into Japanese, Interpreting Research, 16(8), s. 31-41.

Niska, H. 1999, Text Linguistics Models for the Study of Simultaneous Interpreting, Stockholm Univesity http://www.geocities.com/ tolk/lic/licproj_w2wtoc.htm

Pawelec, A. 2000, Spójność tekstu a przekład, [w:] Mała encyklopedia przekładoznawstwa, red. U. Dąmbska-Prokop, Częstochowa, s. 209-216.

Seleskovitch, D. 1978, Interpreting for International Conferences. Problems of Language and Communication, Washington.

Shlesinger, M. 1995, Shifts in Cohesion in Simultaneous Interpreting, Translator 1(2): 193-212.

Snell-Hornby, M. 1988/1995, Translation Studies. An integrated approach, Amsterdam-Philadelphia.

\section{Shifts within lexical cohesive pattern in simultaneous and con- secutive interpreting}

\section{Summary}

The present paper focuses on lexical cohesive markers rendition in simultaneous and consecutive interpreting. Given that each of the modes is governed by the Interpreting Constraints (The Time Constraint, The Linearity Constraint, The (Un)shared Knowledge Constraint, and The Memory Load Constraint) to a different extent, each type of interpreting has been hypothesised to be affected by mode-specific shifts in cohesion. The study aimed to analyse the maintenance of textual cohesion through linguistic resources with the aid of Halliday and Hasan's (1976) model. The type of cohesive devices analysed was reiteration. The results indicate that there is a statistically significant difference between the two modes of interpreting in terms of lexical cohesive patterns rendition. It transpires that retention of the same category of cohesive markers prevails in SI, whereas categorial shifts and omissions are more frequent in CI.

Keywords: translation, interpreting, simultaneous interpreting, consecutive interpreting, shifts, cohesive pattern 